ACTA VET. BRNO, 55, 1986: 285-291

\title{
CHANGES IN BONE TISSUE OF BROILERS TREATED WITH GROWTH PROMOTERS
}

\section{J. NEUMANN}

Department of Post-graduate Studies, University of Veterinary

Science, 61242 Brno

Received April 30, 1985

A b s tract

$\mathrm{Ne}$ u $\mathrm{m}$ a $\mathrm{n} \mathrm{n} \mathrm{J}$.: Changes in Bone Tissue of Broilers Treated with Growth Promoters. Acta vet. Brno, 55, 1986: 285-291.

In three groups of broilers (Ross 1) consisting of 50 birds each and fed rations supplemented with growth promoters (Czechoslovak chinoxaline derivative cyadox, steroid anabolic dimethylandrostanolone, and ionophoric cocciodiostat monensin), cross- sections of femoral epiphyses and diaphyses were observed for histopathological changes and compared with findings in control birds. The samples were collected on days $11,28,42$ and 56 after hatching.

There were no substantial differences observed as to the effects of the three growth promoters on the bone tissue of broilers. Incipient changes in femurs of the treated birds occurred on day 11 , and they became more evident in the course of fattening culminating in 56-d-old birds as against controls. Treatment with growth promoters under study resulted in increased numbers of mesenchymal cells in periosteum and enhanced periosteal apposition. Simultaneously, compact bone medullarized and endosteal resorption occurred. Thus remodeling of long bones in broilers generally ascribed to one-sided selection for meat production is enhanced appreciably in response to treatment with growth promoters.

Broiler fattening, cyadox, dimethylandrostanolone, Na-monensin, femur, histological changes.

In the course of fattening of broilers, changes in the development of their bones, especially the long ones, occur. Such changes have not been observed in laying birds. The general opinion is that the one-sided selection aimed at increased growth rate and a high proportion of musculature results in impaired bone growth (S ile r et al. 1980). Bone growth parameters are characterized by relatively high coefficients of heritability as demonstrated also by selection experiments comparing the changes in body shape and long bone length ( C O CK 1966). Comparison of body and bone proportion ratios and bone composition in broilers 
and in laying strains indicuted that the leg:body size ratio is greater in broilers afte, hatching and later changes (Wise $1970 \mathrm{ab})$. The author found differences also in density and mineral composition of the bones between the two production lines of chickens.

Recently, greater attention has been given to these changes diagnosed in increasing numbers of birds ( $\mathrm{h}$ h a $\mathrm{n}$ e 1982;

Yos hida and $\mathrm{H}$ os hi 1977,1983 ). Apparent long bone defects have been reported in up to $6 \%$ broilers ( $\mathrm{Sh}$ a ne 1982), however, on detailed examination, the diagnosed changes may be present in larger numbers of birds. The factors involved are genetic. disposition, nutritional inadequacies, toxic and infectious factors, and their interactions. The resulting changes comprise rachitis, chondrodysplasia, dyschondroplasia and anchylopodia.

Quantitative analysis of cross-sections of femoral epiphyses and diaphyses in broilers during fattening with use of growth promoters revealed increased numbers of mesenchymal cells of the periosteum, enhanced periosteal apposition and thickening of the bone ( $\mathrm{Neumann}$ and $\mathrm{Straka} 1984 ; \mathrm{Straka}$ and $\mathrm{Neumann}$ 1984). The aim of the present paper is to evaluate the histopathological changes of the bone tissue in these birds as compared to untreated controls.

\section{Materials and Methods}

Broiler hybrids Ross 1 were used in the study. After transport from the hatchery (day 1 after hatching) they were divided in 4 groups of 50 birds each and kept in an experimental hall in cages on wire mesh. All groups were fed a commercial broiler starter ad libitum with drinking water available throughout. The diets for experimental groups 1,2 and 3 were supplemented with growth promoters as follows: group 1 - chinoxaline derivative cyadox at a dose of $100 \mathrm{mg} \cdot \mathrm{kg}^{-1}$, group 2 - fermentation anticoccidic Na-monensin at a dose of $100 \mathrm{mg} \cdot \mathrm{kg}^{-1}$, group 3 - steroid anabolic dimethylandrostanolone (Demalon Spofa) at a dose of $0.5 \mathrm{mg} \cdot \mathrm{kg}^{-1}$. The original commercial starters BR 1 and $B R 2$ were continually supplemented with these growth promoters replacing nitrovin and $\mathrm{Na-monensin}$ that had been replaced by Amprol and ethopabate. The diet fed to the control group contained no growth promoters.

During fattening, 5 chickens of each group were randomly chosen at the ages of $11,28,42$ and $56 \mathrm{~d}$. They were killed by decapitation and femur samples were collected. Samples of epiphyses and diaphyses were fixed for $10 \mathrm{~d}$ in $10 \%$ formalin and sectioned, decalcified for $12 \mathrm{~h}$, using the Liẹvre s solution, rinsed for $24 \mathrm{~h}$ in running water. The samples were then dehydrated in glycerin and further routinely processed. Sections of $7-10 \mathrm{~cm}$ were made using a microtome. The sections were stored in $70 \%$ alcohol and stained using Weigert's hematoxylin. Cleared sections were mounted in Canada balsam.

Apart from morphometric measurements published elsewhere ( $\mathrm{Neumann}$ and $\mathrm{Straka} 1984 ; \mathrm{Straka}$ and $\mathrm{Neumann} \mathrm{1984)}$ histology of femoral epiphyses and diaphyses was investigated in broilers treated with growth promoters and compared with. findings in the control birds. 
Results

In 1l-d-old negative control chickens, the femoral epiphyses showed a marked periosteal ossification with a wide layer of mesenchymal cells. Haemopoiesis was visible only in the centre of the medulla with no bone trabeculae present. Diaphyses contained medullarized compact bone with a developed fine layer of periosteal and endosteal ossification and haemopoietic medulla (Fig. 1).

The first experimental group treated with cyadox showed a medullarized compacta of diaphyses similar to control birds, with more accentuated periosteal layer at several sites. The medulla was haemopoietic. Epiphyses in these birds showed enhanced periosteal apposition, more dense bone trabeculae containing cartilage remnants from endochondral ossification (Fig. 2,6 ).

In chickens of the second group, treated with monensin, changes of long bones were observed as soon as at the age of $11 \mathrm{~d}$. The epiphyses contained more dense trabeculae of cancellous bone showing intense rebuilding in the medulla from high osteoblastic and osteoclastic cells. The majority of trabeculae contained several medium-sized remnants of cartilage in central part of the bone. Diaphyses were medullarized, somewhat thickened with marked appositional periosteal growth and sites with strongly cellular mesenchymal zone of the periosteum. Signs of incipient resorption in endosteal zone were visible. The medulla was haemopoietic (Fig. 3 and 7 ).

In chickens of the third experimental group, treated with dimethylandrostanolane (Demalon Spofa), the medullarized compact bone did not differ from that of the control birds expect for a visible layer of mesenchymal cells in the periosteum. The medulla was haemopoietic. Epiphyses showed intense ossification, the medullar spongiosa became more dense with large remnants of cartilage in the centres of trabeculae.

At the end fattening, i. e. in 56-d-old chickens, femoral diaphyses of control birds (Fig. 5) showed substantially more abundant and irregularly medullarized compact bone with a distinguishable periosteal and endosteal osteoplasia and a visible but not too high layer of cambial cells. The medulla was haemopoietic. Epiphyses of these birds showed a richer formation of trabeculae filling gradually the centre of the medulla. 0steoplasia was intense but the newly formed bone trabeculae did not contain remnants of cartilage. In chickens of the first treatment group (i. e. cyadox), a substantially more intense medullarization of compacta and a wide layer of mesenchymal cells in the periosteum were seen along with subperiosteal bone and medullarization of the entire compacta indicating a remarkable apposition of the bone. Epiphyses showed extremely dense and mature trabeculae of cancellous bone with no remnants of endochondral cartilage present. Osteoblastic rims were high.

In chickens of the second experimental group treated with monensin (Fig. 7), the femoral epiphyses showed less dense spongious bone trabeculae still having larger medullar spaces in their central part filled with haemopoietic tissue. The trabeculae were free of endochondral cartilage. Diaphyses were moderately medullarized with marked signs of periosteal apposition 
from the cellular mesenchymal zone. Endosteal resorption was visible.

In chickens of the third experimental group treated with dimethylandrostanolone the femoral diaphyses were moderately medullarized. The endosteal surface showed conspicuous signs of endosteal resorption. The centres of epiphyses contained larger medullar spaces filled with haemopoietic tissue.

Analysis of present results shows that treatment with pharmacological growth promoters results predominantly in an increased number of mesenchymal cells of the periosteum leading to periosteal apposition, along with gradual enhancement of medullarization of compact bone with more or less marked endosteal resorption. These changes were most pronounced at the end of fattening period but they were encountered earlier, starting in the. second posthatching. week.

Treatment with growth promoters results in multiplication of trabecular bone of femoral epiphyses in chickens as early as in the second week of fattening as against the negative controls. Endochondral ossification was remarkable with large remnants of endochondral cartilage in the central parts of bone trabeculae. In older birds, medullar trabeculae were increased in number, they were mostly mature. On epiphyseal surface enhanced apposition was observed as against the negative controls.

Growth promoters employed in this study affected the bone tissue of broilers in that a more rapid bone rebuilding occurred with increased amount of trabecular bone and enhanced endochondral ossification. Further, periosteal apposition was found on the epiphyseal surface. These findings were encountered in all experimental groups with no different histological features amoung them but they differed from the findings in the control group.

\section{Discussion}

The development of bone tissue in broilers is intense from the very beginning of posthatching life. The bones represent some 17 - 18 per cent of eviscerated carcass in the middle of the fattening period, declining to ll-13 per cent at the end of fattening. However, the one-sided selection aimed at rapid meat production results in bone changes leading to visible defects of legs and impaired locomotor activity of the affected birds (Cock 1966; Wis e 1970ab; Shane 1982). The bone changes in meat hybrid chickens comprise changed proportions of long bones, i.e. their proximal and distal shortening with thickening occurring in parallel. It seems that in practice these changes have been long neglected and impaired locomotion of broilers was not considered a substantial shortage in the fattening process. The finding of more than 6 per cent of broilers suffering from visible leg defects with much larger numbers of birds with various degrees of bone changes ( $\mathrm{Sh}$ a $\mathrm{n}$ e 1982), and occurrence of breast blisters in such birds ( L l o y d 1969; Tok o sová 1981) and possible decreased in body mass gains at the end of fattening have led to more detailed studies of the bone tissue growth in broilers. Further enhancement of body mass increase obtained by use of growth promoters makes the question of bone growth in thus treated birds even more important. 
Histometric studies of the bone tissue in broilers fed growth promoters of the chinoxaline derivatives, steroid anabolics and fermentation substances ( $\mathrm{Neum}$ a $\mathrm{n} n$ and $\mathrm{Str}$ a k a 1984; $\mathrm{Str}$ a k a and $\mathrm{Neum}$ a $\mathrm{n}$ 1984) have shown unequivocally the quantitative parameters of bone tissue (femoral epiphyses and diaphyses) to be affected by these substances. Transverse femoral diaphyse sections revealed an enlargement of the inner and outer surface and thickening of the diaphyseal wall. The mesenchymal layer tended to become thicker in all stimulated groups.

Density of the bone tissue was unaffected by the growth promoters employed in the study. The histological findings in transverse section of femoral epiphyses and diaphyses support fully our histometric data. In stimulated and negative control chickens similar changes were observed to those described as typical of meat strains of poultry as opposed to laying strains ( $W$ i s e 1970). The fact that the changes in microstructure of bone tissue began to occur as soon as at the age of $11 \mathrm{~d}$ shows that growth promoters markedly influence the bone tissue development and enhance occurrence of changes regarded as a result of one-sided selection. No explanation can be offered for essentially identical histometric and histological findings in femurs of broilers fed the three above-mentioned growth promoters. Steroid anabolics are known for their effect upon human bone tissue and may be employed in treatment of osteoporosis ( $G$ a s e k 1963). In the present study, no relationship was established between the intensity of growth promotion and rate of bone development; so monensin with the least growth stimulating effect affected bone development in a manner similar to cyadox exerting in turn the most pronounced growth stimulating effect.

\section{Změny kostní tkáně kuřecích brojlerú $v$ prủběhu farmakostimulace} rústu

Při ovlivnění výkrmu brojlerủ farmakologickými stimulátory rủstu, a to chinoxalinovým derivátem Čs. pưvodu cyadoxem, steroidním anabolikem dimethyladrostanolonem a ionofórovým antikokcidikem natrium monensinem dochází k výrazným změnám na kostech končetin. Histopatologické změny na přičných řezech epifýz a diafýz femuru sledované $v$ několika etapách postinkubačního vývoje brojlerů ROSS l ukázaly, že $v$ pưsobení jednotlivých typủ použitých stimulátorú nejsou podstatnější rozdíly, že ve srovnání s kontrolní skupinou se tendence ke změnám na kostech projevují již v druhém týdnu výkrmu a že tyto změny vrcholi v závěru výkrmu, $t j$. $v$ jeho osmém týdnu. U všech použitých stimulátorù dochází k zmnožování kambiálních buněk periostu vedoucímu $k$ zvýšené periostální aposici. S tímto úkazem je spojeno současně i postupné zvyšování medularizace kompakty spojené s endostální resorpcí. Látky stimulujicí rủst zpủsobují tedy rozšíení kostí běhákư zvýšenou periostální aposicí. Vlivem farmakostimulace dochází na kostech $k$ prohloubení těch změn, které jsou u masných hybridů obecnè přisuzovány jednostranné selekci zaměřené na intenzivní zvyšování masné produkce. 


\author{
Изменения костной тхани хуриных бройлеров \\ в ходе фармахостимуляции роста
}

Оказывая влияние на отхорм бройлеров фармахологическими стимуляторами роста, а именно химихсалиновым производным чехословацхого происхождения циадохсом, стероидным анаболичесхим препаратом диметиландростанолом и ионофоровым антикокцидическим веществом натрий монензином, происходят выразительные изменения на костях хонечностей. Гистопатологические изменения на поперечных срезах эпифиза и диафиза бедренной хости, наблюдаемые в течение нескольких этапов послеинхубационного развития бройлеров РОСС 1 выявили, что в воздействии отдельных типов используемых стимуляторов не наблюдается существенная разница, что по сравнению с хонтрольной группой тенденции, направленные на изменения костей, проявляются уже на второй неделе отхорма и завертаются в заключение отхорма, т.е. на воцьмой неделе. у всех используемых стимуляторов происходит умножение камбиальных клетох надкостницы, выливающееся в повышенную периостальную апозицию. С упомянтым явлением одновременно связано постепенное увеличение медулляризации хомпактного слоя, связанное с эндостальной резорбцей. Следовательно, стимулирующие рост вещества вызывают расширение костей конечностей периостальной апозицией и по сути дела под влиянием фармахостимуляции на костях более интенсивно происходят изменения, связываемые у мясных гибридов с односторонней селекцией, направленной на интенсивное повышение продухции мяса.

COCK, A. B.: Genetical aspects of metrical growth form of animals. Guart. Rev. Biol., 4l, 1966: 131-190.

GAŠEK, T.: Anabolicky účinné látky. Lékařská věda v zahraničí, 4, 1963: $70-75$.

LLŌYD, R. W.: Growing broilers in cages. Poult. Digest., 28 ,
1969: 542 - 545.

NEUMANN, J. - STRAKA, I.: Histometrická analýza kostní tkáně brojlerú při výkrmu ovilivñovaném farmakologickými stimulátory rustu. Paper at the XVII. Conference on Poultry Physiology, VSZ Praha, august 1984 .

SHANE, M. S.: Skeletal abnormalities in broilers. Poultry Digest., 41, 1982: 544 - 551 .

STRAKA, I. -. NEUMANN, J.: A method of histometric analysis of chicken bone tissue. Acta stereologica (Ljubljana) in print.

SILER, R. - KNIZ̈E, B. - KNIŽETOVA, H.: Rúst a produkce masa u hospodářských zvířat, SZN Praha, 1980, $276 \mathrm{p}$.

TOKOSOVA, M.: Stúdium vplyvu niektorých rast stimulujúcich látok na kvalitu a kvantitu mäsa kurčiat a ich potencionálneho účinku na rozvoj neoplastického bujnenia. PhD. Thesis. VSV Košice, 1981 , $185 \mathrm{p}$.

WISE, D. R.: Carcass conformation comparisons of growing broiler and laying strain chickens. Brit. Poult. Sci., 11, 1970:
$325-332$. 


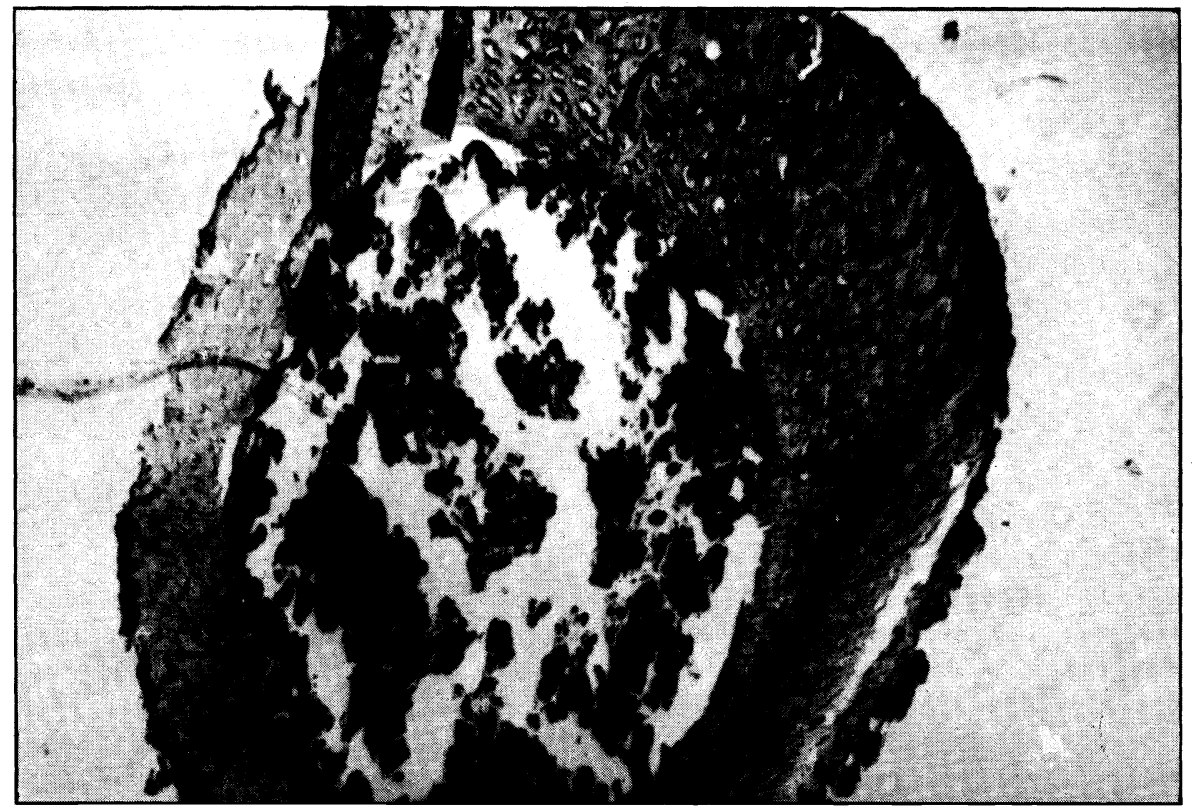

fig. 1

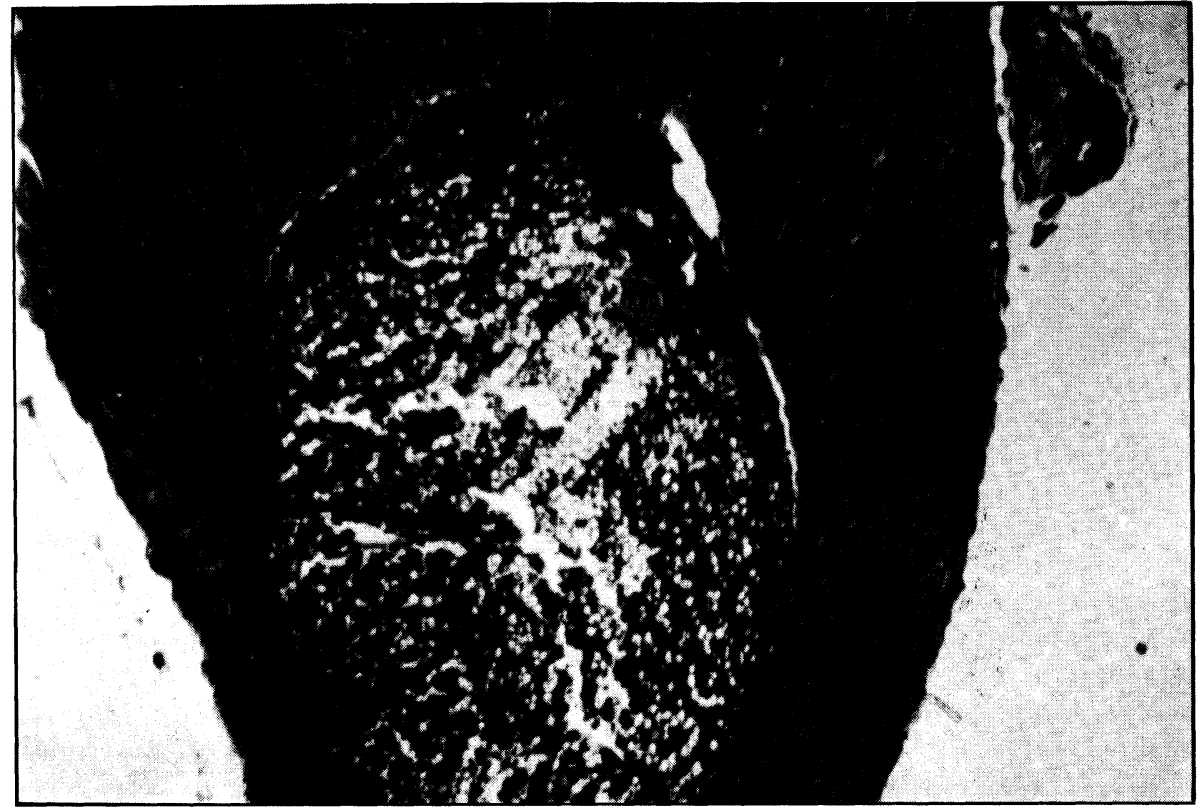

Fig. 2 


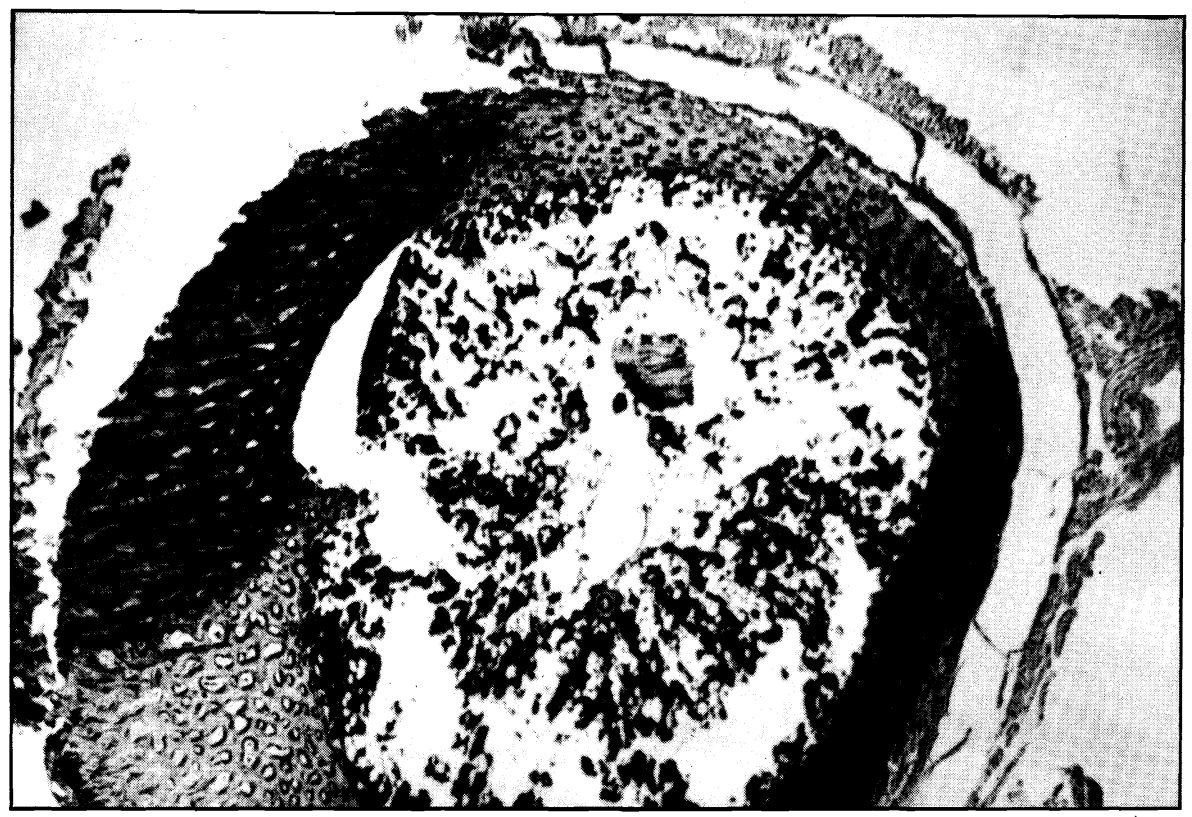

Fig. 3

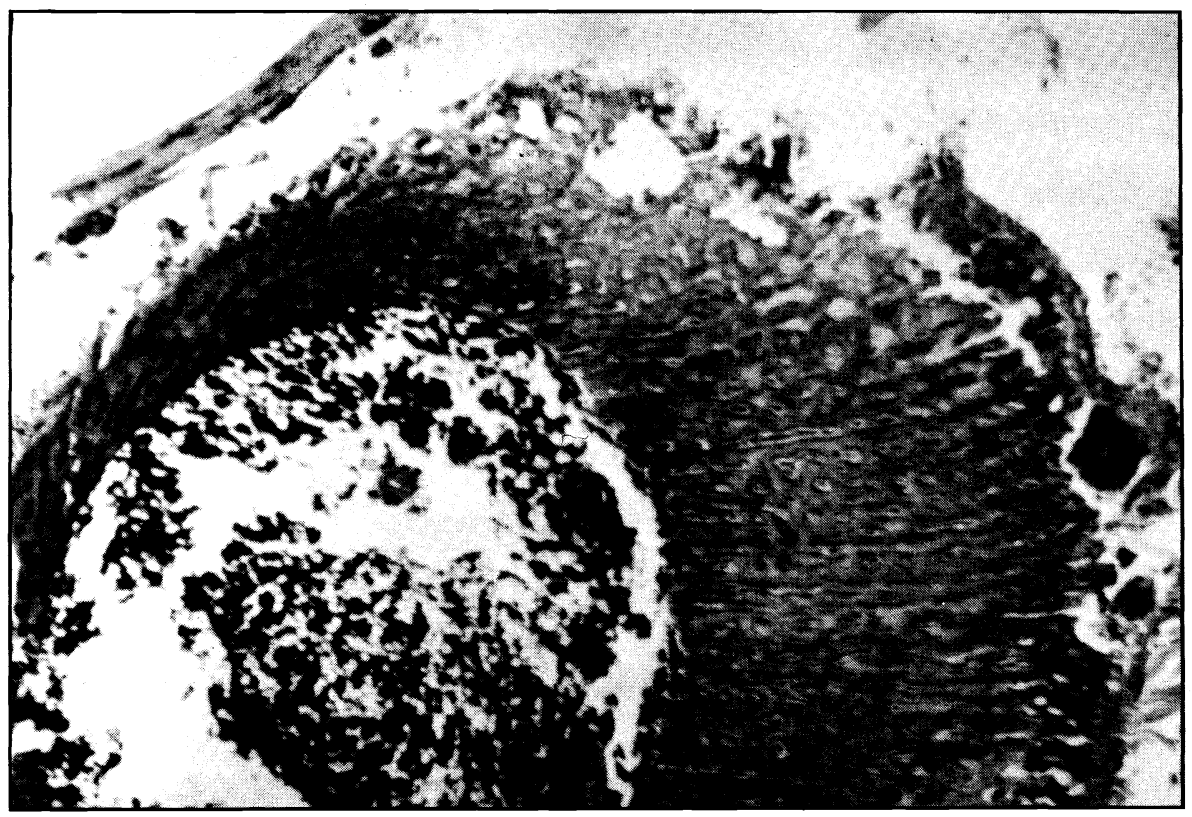

Fig. 4 


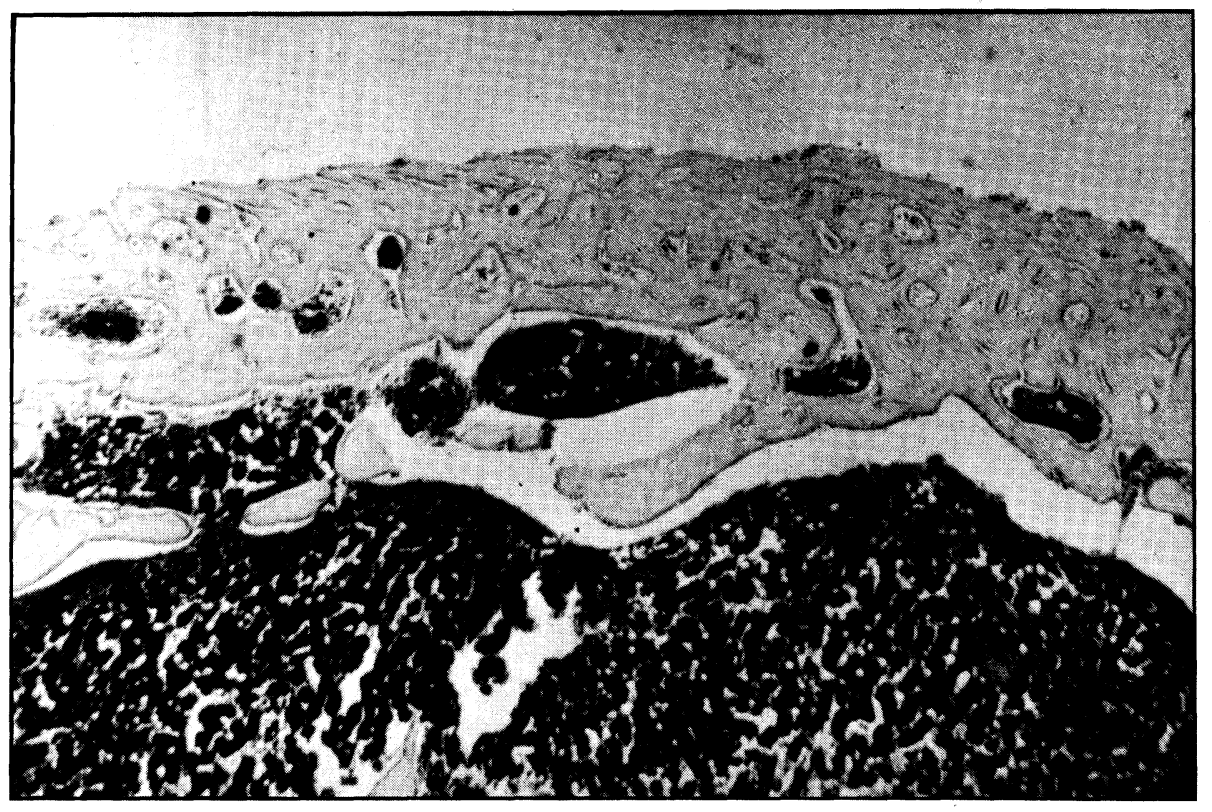

Fig. 5

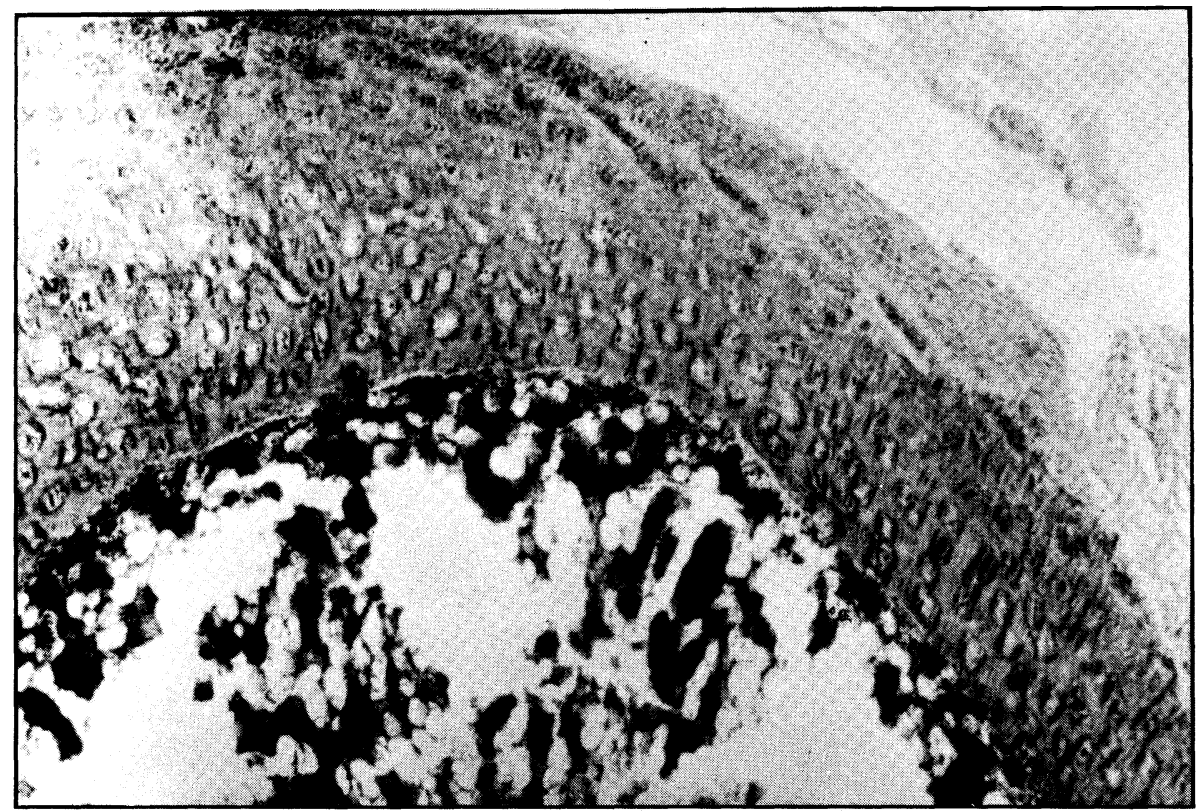

Fig. 6 




Fig. 7

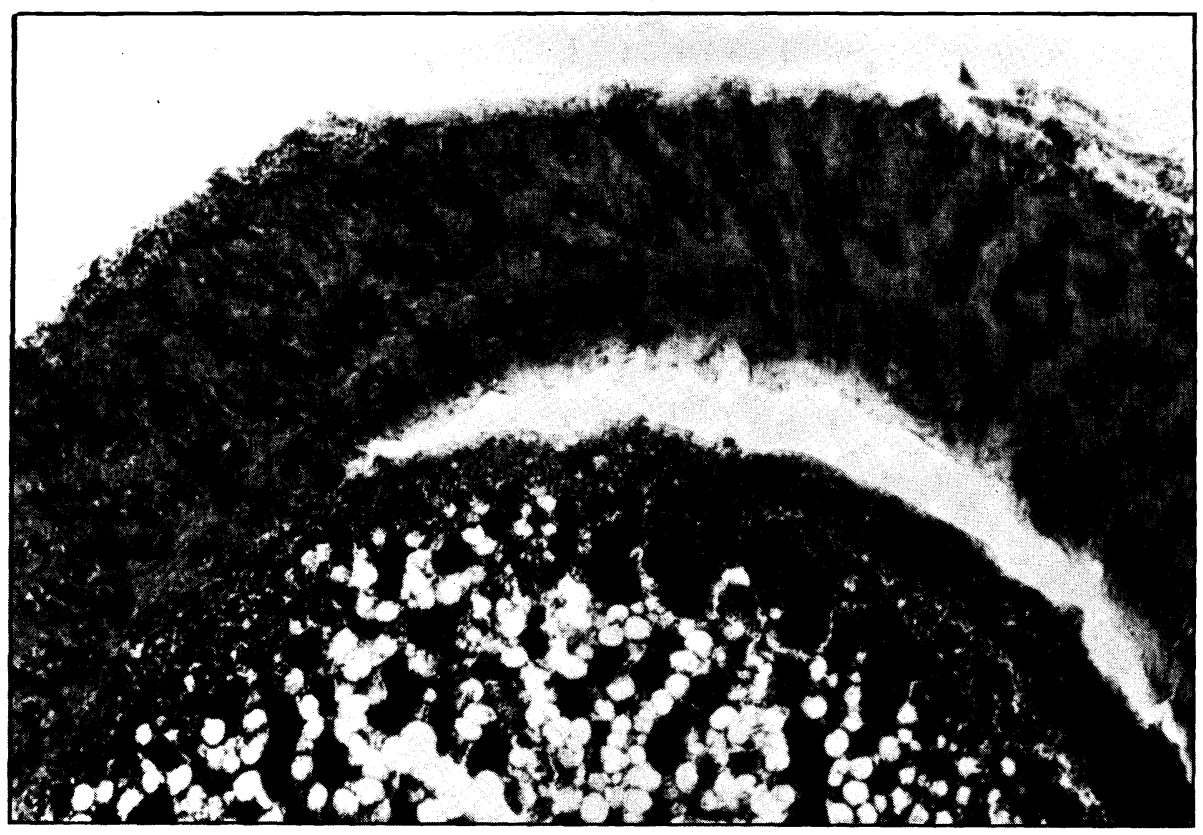

Fig. 8 
WISE, D. R.: Comparisons of the skeletal systems of growing broiler and laying strain chickens, Brit. Poult. Sci., $\underline{1}$, 1970: 333 - 339 .

YOSHIDA, M. - HOSHILI, H.: Improvement of biological assay to determine available phosphorus with growing chicks. Japan Poult. Sci., 14, 1977: 33 - 44 .

YOSHIDA, M. - HOSHII, H.: Relationship between Ach Contents of the Tibia Bone and the Toe of Chlcks. Japan. Poult. Sci., 20, 1983: 51 - 54 .

Texts to figures:

Fig. 1. Femoral diaphysis of an 11-d-old broiler, negative control. Moderately medullarized compact bone with conspicuous periosteal and endosteal layer and with haemopoietic medulla. $\mathrm{HE}, \times 32$.

Fig. 2. Femoral diaphysis of an ll-d-old broiler treated with cyadox. The picture not different from Fig. 1; relatively thick periosteum, haemopoietic medulla. HE, $\times 32$.

Fig. 3. Femoral diaphysis of an 11-d-old broiler treated with monensin. Medullarized and at sites wider compact bone with preserved cellular periosteum (upper right-hand side) and with incipient resorption of endosteal surface. HE, $x 32$.

Fig. 4. Femoral diaphysis of an 1l-d-old broiler treated with dimethylandrostanolone. Focal increase in number of mesenchymal periosteal cells at several sites. HE, $x 32$.

Fig. 5. Femoral diaphysis of a 56-d-old broiler, negative control. Large areas of irregularly medullarized compact bone. The periosteal surface with no changes, haemopoietic medulla penetrating the areas adjacent to medullarized compacta. HE, $x 80$.

Fig. 6. Femoral diaphysis of a 56-d-old broiler treated with cyadox. Thick layer of appositional newly formed periosteal bone attached to medullarized compacta with uneven endosteal surface and numerous resorption wells. HE, $x 80$.

Fig. 7. Femoral diaphysis of a 56-d-old broiler treated with monensin. Medullarized compact bone with conspicuous periosteal bone apposition and endosteal resorption. Thickened and cellular periosteum doubles the bone diameter at sites. The limit between bone and periosteum is not clear. $H E, \times 80$.

Fig. 8. Femoral diaphysis of a 56-d-old broiler treated with dime ihylandrostanolone. Medullarized compact bone with strongly cellular periosteum not clearly separated from the bone, and with cellular uneven and resorbing endosteal surface. HE, $x \quad 80$. 